\title{
DALIA MOGAHED'S IDENTITY AS REFLECTED IN TED TALKS VIDEO
}

\author{
Zaenul Kurniawan Syahid \\ HIMLU Malang, East Java, Indonesia \\ zaenulkurniawan@gmail.com
}

\begin{abstract}
This study discussed the identity of Dalia Mogahed reflected through speech in an event called TED Talks. It is a big program have been featured great people around the world including Dalia Mogahed from various backgrounds to spread ideas. Her 2016 TED Talks entitled "What it's like to be Muslim in America" was named one of the top TED Talks that year. This research employed a descriptive qualitative method as a research design since the purpose of the study is to provide a deep analysis of the data. The data collected through the transcription which is provided on the TED Talks official website. The finding revealed that Dalia Mogahed projected her social identity more dominant than role identity. There was no indication of the utterances that proved the characteristics of her personal identity. Therefore, the fluidity of identity was also shared by Mogahed in that situation to convince that identity was not fixed. It is highly recommended for further researchers who are interested in investigating the personal identity projection to follow up the findings of this research by concerning on finding someone's personal identity in term of speech performance.
\end{abstract}

Keywords: Sociolinguistics, Social Identity, Role Identity

\section{INTRODUCTION}

Identity becomes one of an interesting issue today, as Marcer (1997) said that "just now everybody wants to talk about identity". Moreover, identity is built through both symbolic and sociocultural contexts, which generates the opportunities of who we are and what we can become (Woodword, 1997). As a human being, human attempts to build their identity by distinguishing their place as a person or group by differences and similarities. Based on the statement by Woodword (1997), contradictory of the identities are situated within the social, political and economic adjustments to which they contribute and appear through certain aspects such as nationality, gender, and society. Human beings have a deep tendency to identify, assess and analyze their identity since "every human society from the simplest to the most complex has a means by which members differentiate themselves from one another" (Newman, 2012). 
According to Omoniyi and White (2006) "identity focuses on the ways in which people position or construct themselves and are positioned or constructed by others in sociocultural situations through the instrumentality of language and with reference to all of those variables that are identity markers for each society in the speech of its members". To strengthen Omoniyi's concept, Dickerson (1996: 21) also stated that "resolution lies in the utterance turn rather than the activity as a whole however does not resolve the problem in that situation in which multiple identities are articulated within the same utterance turn". Furthermore, people might have more than one identities based on their social rule. As Hyland and Paltridge (2011: 260) have said that "human being as social actors have multiple identities which are determined by the configuration of social context. Beside that identity showed who we are and what we are in both personal and social life (Blommaert, 2005: 153).

This research specifically investigates Dalia Mogahed's identity represented in her speech on the TED Talks video. She is an author, Muslim speaker, director of research at the Institute for Social Policy and Understanding and the former director of Gollup Center for Muslim Studies. Also, she becomes the first hijabi in the White House since she was appointed to a position in President Barack Obama's administration as an advisor (Challouki, 2015). It is necessary to know that TED is a nonprofit platform devoted to spreading ideas, usually in the form of short, powerful talks (usually 18 minutes or less). Basically TED began in 1984 as a conference where Technology, Entertainment and Design converged, but today covers almost all topics from science to global issues in more than 100 languages.

Further, Identity has been an intriguing issue in the last few decades due to the issue of identity crisis faced by many countries (Susilowati, 2014). There are some studies concerning identity, such as Molalita (2006) on the identity construction of Najwa's Character as Jordanian Muslim Woman in The Willow Trees Don't Weep novel. Her research supported by the concept of identity of Stuart Hall. There is also Azizah (2014) who is researching JK Rowling identity representation in Oprah Winfrey Show. Her study focused on the personal identity of the object on how J.K Rowling showing her identity based on interview. While, this research aimed to understand deeply how Dalia Mogahed projects her identity on the TED Talks program.

\section{LITERATURE REVIEW}

\section{Identity}

The focus on identity in social sciences has enormously increased in few decades. According to Hall (1997), the identity used to recognize individuals. It obviously determines what individuals represent themselves to other individuals and how they perceive each other. This explanation draws individuals to mean us as "someone" who is later marked with some socio-cultural attachments. Block (2007) said, "Identity is also related as it is built through symbolically labelled social interactions". This can occur in 
face-to- face interactions as well as in electronically mediated communications with variable degrees of shared convictions, values and experience.

According to Burke (2009), an identity pointed out the definitions and meanings that define an individual when he or she is in a group of individuals, a member of a particular community or group, or declares one of the features that classifies him or her as a distinctive individual. The examples are that each individual has representative meanings that they point to themselves when they are a student, parent, teacher, wife or employee (these are the roles they occupy). It also happens when they become a member of a brotherhood, when they belong to the political party, when they are Latino (these are memberships in specific organizations). Or, when they claim to be outgoing individuals or morals (these are specific qualities that identify as distinctive people).

As Cooley (1902) pointed out, there are two sides of the same coin between the person and society. Like Coleman (1990), Stryker (2002), and others say, "we believe that the activities of people generate community (social structure), although it is acknowledged that these actions are generated in the context of the social structure that they produce and are affected by this framework". Understanding the social structure its forms and patterns can develop and transforms someone's identity (Burke and Stets, 2009).

People can change identities to suit the needs of moment identity cannot be categorized or classified. As stated by Omoniyi (2006), Individuals can move in and out of identity as identity is specifically fluid. Because when people represent their identity, they not only bend on their utterances but also how they measure and respond against what happens on their circumstances (Pearson, 2004).

There are a number of researchers have been doing research within identity study and language with different subject and approaches. However, the previous researcher focuses on one research which is considered very significant in discussing identity. Susilowati (2010) investigated teacher identity by using ethnographic action research. She saw identity representation in the classroom perceived by both teacher and student. Teachers consciously or subconsciously made effort to shape their student's identity (Susilowati 2010). By ranging from designing classroom activities, material selection, or conducting follow up activities, even before the teaching was executed, the teacher could shape their student's identity. Meanwhile, from the student's perspective, the use of particular language and some linguistics features could be the way how the students detected their teacher's identity.

\section{Sociolinguistics and Identity}

In the field of sociolinguistics, identity can be more elaborated within the sociolinguistics limit. According to Omoniyi \& White (in Susilowati, 2014), identity has six particular features. First, identity is not fixed, which means that identity is fluid and not permanent. Secondly, identity is built within an existing framework and may differ from a context to another context. This implies that the context obtained or constructed by 
someone impacts the identity significantly. Third, identity, which moderates, defines and transforms these environments by intervening social factors and expressed through language-based., it means that identity does not stop at the context but also the environment and language used as a communication tool. Fourth, that identity is a prominent factor in every communicative context, whether it is given prominence or not, when a communicative scenario takes somebody to choose between displaying their identity or not. Fifth, this identity influences social interactions and thus also informs the communicative exchanges that defined them.

Joseph (2004) stated that 'identity of identity' is contentious. The aim of identity is constituting a frame of reference which is known as recognition of an entity takes place, it was a concept. Joseph divided the dimensions to know the process of recognition, there are the cognitive (abstract, mental) and the physical visual (normative, social). The first aspects which human could directly observe while the latter be inferred from other phenomena are behaviours and actions. The dissimilarity is among the objective reality that named approval, and the imagined or perceived that named description.

\section{The Basis of Identity Theory}

In understanding more about identity, there are some ideas come out from the experts. They have the paradigms to extend the development of identity theory. First of all, here we turn to Sheldon Stryker who is one of the originators of the identity theory. Stryker (1980 [2002]) pointed "a person has an identity or an internalized position designation for each of the different position or roles the person holds in society". It means if a person has the position of wife, she automatically corresponding wife identity, is also if someone holds the position as a worker, he or she has the corresponding worker identity.

Person identity is the uniqueness and the distinctness of someone that makes her/him different from others. The person identity could be relevance with the role identities. However, in all circumstances, people's identity is more probable to beactivated than role models because they refer to significant individual elements. People do not "put on" and "take off" these characteristics because they may "take" and then "out" certain roles. Hence, the influence of the identity of the person on the identity of the role and the choice of group identity assumes that the individual is in a society in which the group's roles and membership are voluntary; in less open societies where people have fewer choices of roles and groups, the identity of people is likely to be formed more by roles and groups assumed by individuals than otherwise (Burke, 2004).

Role identity is the main significance of identity theory. A role offers each self and circumstances with the structure, institution, and significance. Role identity is influenced by the social position of an individual. In general, role identities consist of a big number of meanings. Therefore, individuals can switch to more than one feature to define what the function or role means to them (Burke and Stets, 2009). Further, for the same role 
identity, various persons may have different interpretations. If the meanings of the role of identity are not shared, people should negotiate the meanings with other people who have the distinct comprehension of that identity (McCall and Simmons in Burke and Stets, 2009).

The next basis of the identity is about social identity. It is based on the recognition of an individual with a social community (Hogg and Abrams 1988). In addition, having a certain social identity implies being in a group like someone else and looking at stuff from a group view. it means that people as members of a certain group have to think in the same way and act the same way as the other. Thus, there is consistency in thinking and acting to become a group of individuals. Furthermore, the position of social identity and we are as a member of the group would verify the feeling of belonging and upgrading a person's self- worthiness (Stets and Burke, 2009). With a high level of self-worth, individuals have a level of emotional stability that grants meaning and significance in their life.

\section{METHOD}

This study was categorized as qualitative studies because of several points. First, the primary aim of this study was to know how Dalia Mogahed projected her identity in the TED Talk program. Secondly, this study used the researcher to collect the data. The last, all of the data in this research were in the forms of soft data that contain utterances. Furthermore, it was classified as descriptive research on how Dalia Mogahed represent her identity through the speech at the TED Talks program. Dornyei (2007) stated that "qualitative is playing a role in describing, understanding and clarifying human experiences. It also accomplished by describing and understanding language use, which is later clarified as one's identity". Meanwhile, this research was included in descriptive qualitative since it provided sensitivity of description during the analysis.

The first data of this study was taken from a video in TED Talks program. The video showed Dalia Mogahed as the influential Muslim women delivered a short powerful speech that premiered in February 2016. The form of data is the speech of her. The video was downloaded from the TED Talks website which was released in 2016 entitled: "What it's like to be Muslim in America". The second source of information is speech transcription. The transcription of this study was taken from TED Talks transcript (2016).

To collect the data, firstly the researcher discovered the video on TED Talks website with the keyword "Dalia Mogahed TED Talks" then download the video from that website. Therefore, the researcher checked the video to make sure that the video and the transcription were completely downloaded. The next step is to make sure the validity of the transcription. Then, the researcher fixed the script while watching the video source for many times. The last step is selecting and writing down the utterances of Dalia Mogahed, which indicates her identity. 
In conducting data analysis there are three steps according to Miles \& Huberman (1992), Firstly, data reduction relates to the process of choosing, concentrating, modifying, categorizing and transforming information that appears in writing field notes or transcriptions. The second is the display of data, structured information that allows the drawing of conclusions in practice. Based on the step above, the researcher choosed Dalia Mogahed's utterances, which contains all the information about her identity. Thirdly, analyzing the selected data by using the identity theory of Burke and Stets. The last is evaluation, drawing and verification, based on the subject speech and data collection; the investigator concluded that the use of language can observe an individual with more than one identity in a single time or context and identity.

\section{FINDINGS AND DISCUSSION}

This research focuses on the discussion and elaboration on the social identity of Dalia Mogahed sourced from her speech delivered through the TED Talks stage. In his journey as a person who has a big contribution to the development of Islamic society in America, Dalia often finds a variety of unfavorable treatment from the surrounding Non-Muslim communities. Islamophobia is one of the biggest challenges of the American Muslim community. Islamophobia is often used as a political tool to obtain the goals or interests of a group. Therefore, in his opportunity as one of the speakers at TED Talks, Dalia conveyed her complaints as a minority who lives in the frame of the country that embraces democracy as a principle of state.in other side, Dalia also conveyed several important matters concerning the vision and mission of the American Muslim community as well as the rights that must be maintained by all elements in the state order. So that in her speech various identities appeared that represented herself. She did it all to attract the sympathy of the community to be able to understand Muslim society from a different perspective.

In the very beginning, the researcher looks at the definition of identity through some experts. According to Burke (2009), identity means that define an individual when he or she in a group, a member of certain community or group, or declares one the feature that categorizes him or her as a different individual. Hall (1997) also stated the identity used to recognized individuals, obviously determines what persons represent themselves to other persons and how they perceive each other. Identity is also related as it is built through symbolically labeled social interactions (Block, 2007). Through all of the definitions above we got that Dalia defines herself to group of people as a Muslim and represents herself as a representative of American Muslim community. As she said "I'm a practicing, spiritual Muslim. But not like Lady Gaga says, because baby, I wasn't born this way. It was a choice". In the line of Block (2007) concept that says, identity is also based and built through social interactions. Then it was labeled to Dalia when she wore the hijab during her performance on the stage as a symbol of a Muslim fashion. It is happened because of her social interactions with the Muslim community where she lives. 
Coleman (1990) and Stryker (2002) say, "we believe that the activities of people generate community (social structure), although it is acknowledged that these actions are generated in the context of the social structure that they produce and are affected by this framework". The activity that has been carried out by Dalia on the stage aims to convey something to create a collective understanding between the audience and those who will hear it later on. This activity shows the existence of social interaction activities between the speaker and audience, which then forms a community called TED Talks. all activities carried out by people collectively will create a new behavior or community, in other words, the formation of a new community is built through the ideas conveyed by members of the group. The identity also might be talking about how people act to protect, establish and verify the conception of who there are in some situation. Then at the moment, Mogahed established and verified herself as a Muslim who stands for humanity to fight all about islamophobia around the world. This all she did to protect her community's values and faith.

\section{Role Identity}

The first identification is role identity, which is the tied meaning of a role that someone associates to him or herself. Burke (2009) said that "the different position of someone in society will create different role identities further". such as at the first datum (datum 1), she said in the beginning of her speech "an expert?', so it means her role in the society is an expert of Muslim analysis around the world. it was proven by the number of analysis she did and the contribution on Islamic community development. Her role identity as an expert that internalized meanings of her occupation as the director and analyst of ISPU (Institute for Social Policy and Understanding) and any other Muslim organizations. In other words, a circumstance where she lives also affected her role identity, in this case, her institution establishes her thought to defend her surroundings including the existence of the Muslim community.

The second datum (datum 3) also shows her role identity as religious Muslim that she always practices her religious teachings. further, she presents her identity as a mom which is picturing she has married and has children. When introducing himself, Mogahed mentions many things that are consistent with the fact that he is a devout Muslim, a mother, and loves espresso coffee. Not without reason, Dalia shows her obedience by still wearing clothes that cover her whole body because in Islam it is ordered for women to keep covering their 'aurat' (body parts required by Islam to be covered). then following what was said by Burke, Dalia's role identity as a Muslim is influenced by the surrounding circumstances. Known Mogahed lived and grew up in Muslim families and the American Muslim community. it is not wrong if he is a representation of a devout Muslim. then related to the statement that calls herself a mother and likes some things, the goal is to convey to the audience that she, like humans in general, still carries out her obligations as a mother to her children and husband. if seen from the concept put forward by Omoniyi, 
that identity is not fixed and can change at any time according to the place and condition at that time.

Subsequent data (data 9) shows Mogahed's role identity as a Muslim activist. the role of the activist as known by the general public is to work actively to encourage the implementation of something that is in the interests of his group, it can be organizational, political, social, labor, farmers, students, women, and others. If we see from the definition above, Mogahed, in this case, has conveyed a group interest, namely the Muslim community specifically and the whole Muslim community around the world. From his statement that says "The choices don't make sense, because it's the wrong question. Muslims, like all other Americans, aren't a tumor in the body of America, we're a vital organ" indicates the construction of defense against a group that is the task of an activist.

Theoretically, as what she said on the TED Talks stage was in line with the concept initiated by Burke \& Stets that a role is a set of hopes, assumptions and even values related to social positions which then can guide one's attitudes and behavior. For example, the social position of "student" means having a role in learning new knowledge and skills, dealing with academic activities and so on. Likewise, with the social position of "teacher" is a form of expectations for knowledgeable, instructive, mentors and so on. So, in this case, Mogahed stated a sentence of defense against the Muslim community "Muslims, like all other Americans, aren't a tumor in the body of America, we're a vital organ" as a form of expectation of his role identity as an activist.

The next data (data 10) illustrates a conclusion from the speech that Mogahed delivered. she said that Muslims, in general, want very basic things. They want prosperity for themselves and their families, have jobs and live in peace. as a humble person, Mogahed added "I would say, don't let this stage distract you, I'm completely ordinary. I'm not an exception. My story is not unusual. I am as ordinary as they come (Muslims around the world). the statement proved that she wanted to show herself as a humble person. because it does not mean she can be on the TED Talks stage as an exception that she works in a leading organization and others, then tells all the events of what happened to him personally. but what she told toward the audiences was based on what she has found in other Muslim communities around the world through very comprehensive research.

Through this case, the researcher found the statement "I've done the largest study ever done on Muslims around the world" which is an indication of Mogahed's role identity as a researcher. This is following the concept of role identity initiated by Burke and Stets and other experts. Apart from the meaning of the role identity that has been outlined in the previous session, the meaning of the role identity also has a connection with the meaning implied by the habits of one's behavior. There is a correspondence between the meaning that a person attaches to his identity with his behavior (Burke and Reitzes, in citation of Burke and stets, 2009). for example, in the Burke and Stets's identity theory book says, if the role identity is "student" then the appropriate behavior becomes academically 
responsible, attends class, completes assignments, and then passes the test (Burke and Stets, 2009). It is appropriate if Mogahed's role identity is then as a researcher. Because in his behavior shows the activities as a researcher. it is known that she works as a director (ISPU) and former director at the Gallup Center for Muslim studies. Mogahed also published a work in the form of a book entitled "Who Speaks for Islam".

\section{Social Identity}

The second category of observations is about social identity, researchers found 6 data included in the category of social identity. but before elaborating on these findings, the researcher will first mention the basic theory of social identity. as mentioned by Hogg and Abrams in Burke and Stets (2009) that Social Identity is based on the identification of a person with his or her social group. The intended Social Group is a group of individuals who give the view that they are part of the same social category (Burke and Stets, 2009). having a particular social group means being like other people included in the group and seeing things using the point of view of the group itself. this view assumes that individuals as part of a particular group have the same mindset and behave in the same manner in accordance with the values shared by the group.

In line with the concept above, the researchers will present Dalia Mogahed's Social identity. The first, that is, in (datum 2) shows his social identity as a Muslim. it is represented by the words "That's just how the media has been portraying people who look like me". The phrase "people who look like me" explicitly indicates that he is a good Muslim because when he was on stage she wore a Hijab and a dress that symbolized a Muslim. as a Muslim, the values taught in Islam must be maintained and applied in everyday life. in the end, what Burke and Stets (2009) call social identity is very much in line with the behavior shown by Mogahed who sees and behaves in accordance with the norms of Islam.

Furthermore, the concept of social identity is also related to the prototype. The prototype in question is related to some perceptions, attitudes, feelings, and behaviors that describe similarities within group members and the differences between ingroup members and outgroup members (Hogg, 2006). in line with the concept, the researcher found Mogahed's social identity in (datum 4) that she is a representative of good Egyptian "And so later, I got married, and like all good Egyptians, started my career as an engineer." needs to be underlined that the words "Egyptian "as a group where Mogahed is a member of that group. this was expressed because indeed he was born in Cairo to an Egyptian family as well. then Mogahed was known to be an Egyptian immigrant who settled in America now.

She revealed the prototype as a good Egyptian in the phrase "started my career as an engineer". according to her, to be a good Egyptian at least have some criteria, one of which is to become an engineer. the reason for saying this is departing from the perception of Egyptian society in general that most Egyptian people started the profession as engineers. 
social identity like this which then becomes evidence of the similarity of perceptions that occur in the environment of the ingroup (Egyptian) of Dalia Mogahed.

The third datum (datum 5) emphasis on her social identity as nationalist. Burke says, having certain social identities as a member of the group means to activates the sense of belongingness and builds up someone's self-worthiness. Then, the feeling of self-worth increases when individuals follow groups and they feel accepted and are judged valuable on the principle of who they are and not what they do (Burke and Stets, 2009). Therefore, it is proven from Mogahed's sentence which says "I was living essentially the Egyptian-American dream" due to the belongingness to a certain country and also having the same dream as American citizenship. As a nationalist, she always stands to maintain the religious harmony in America through her research, speech, and policies.

The following data (datum 6) shows the citizenship identity of Dalia Mogahed. this can be seen from the sentence "Not only had my country been attacked, but in a flash, somebody else's actions had turned me from a citizen to a suspect". the sentence "my country" then refers to a country that is the United States because it is known that Mogahed currently resides in the united states after immigration from Egypt to America when she was 4 years old. the concept of citizenship according to T.H. Marshall in his book "Citizenship and Social Class" is a status that is given, awarded, attached by a political community in this case is the state to the citizens who are being members of it. the status means, a set of basic rights which include social, political and civil rights. social rights relating to guarantees of security and proper welfare as fellow citizens. Thus citizenship implies equality formally, legally and formally. this is what creates citizenship status.

Having citizenship as a United States citizen later became a social identity for Mogahed. Meaning that having a social identity as a member of a particular group (American citizen) means activating a sense of belongingness to the group or country and increasing self-esteem (Burke and Stets, 2000). as one example of belongingness shown by Mogahed is to be a person who always maintains security and creates security in America against the rise of Islamophobia after the September 11 tragedy.

After the September 11 attacks, it emerged later in various American media that the perpetrators behind the tragedy were from Muslim groups. This kind of thing eventually led to negative stigma among American society which accused Muslim groups as terrorists and then triggered anti-Muslim movements. Because of that negative accusation which has alienated the Muslim society, then Mogahed decided to speak that it was not true. Therefore, what Mogahed really want is to straighten out about this negative perception of Muslims. Through this TED Talks stage, she gives a real view of Muslims to eliminate that negative stigma.

Acording to her Islam is not a religion that justifies acts of terrorism, even she condemned the perpetrators of terrorist crimes by saying "And yet, something didn't feel right. I get it that people were angry at the terrorists. Guess what? So was I ". Datum 7 then 
shows Mogahed as a representative of a Muslim group she would have positioned herself in a group of people who condemn acts of terrorism. From her statement, it can be concluded that he is upset about what has happened so far that consider Muslims are terrorists. Therefore, through the TED talks stage he formed his social identity as an AntiTerrorism person.

The third category of identity theory initiated by Burke and Stets is about Personal identity. Based on the basic concept stated by Burke and Stets that personal identity is uniqueness and difference that makes individuals different from others (Burke and Stets, 2009). Unique is meant namely idiosyncratic personality traits that are not shared with others (Hogg, 2006).

If it is associated with the concept, the researcher did not find any personal identity that was highlighted by Mogahed when he was on the stage of TED Talks. Because researchers do not find the characteristics or indications of unique individuals that are in accordance with "idiosyncratic personality attributes". The characteristics referred to as "idiosyncratic personality" are; (1) Inner life; Idiosyncratic individuals are tuned in to and sustained by their feelings and belief systems, whether or not others accept or understand their particular worldview or approach to life. (2) Own world; they are self-directed and independent, requiring few close relationships. (3) Own thing; Oblivious to the convention, idiosyncratic individuals create interesting, unusual, often eccentric lifestyles. (4) Expanded reality; open to anything, they are interested in the occult, the extrasensory, and the supernatural. (5) Metaphysics; they are drawn to abstract and speculative thinking.

(6) Outward view; though they are inner-directed and follow their own hearts and minds, idiosyncratic men and women are keen observers of others, particularly sensitive to how other people react to them (Oldham, John M., and Lois B. Morris, 1995).

\section{CONCLUSION}

Based on the findings and discussions conducted by researchers in the previous chapter, it can be concluded that the object of research, in this case, Dalia Mogahed projects her identity through the use of language into two categories, namely Role identity and social identity. Actually, in the primary theory of identity applied by the researcher, there are 3 categories of identity; Role, Social, and Personal. But the last category about personal identity did not appear in her speech because there was no characteristic or the clue represented about her uniqueness with others. Furthermore, the 10 data found in the finding shows 4 data included in the Role Identity category and 6 other data included in the Social identity category.

Through the categories mentioned above, Dalia Mogahed then projects her identity by bringing up her social identity more dominant and salience than the other categories. This is because she talks more about the groups or communities she has defended and fought for. Furthermore, regarding Role identity, he showed by bringing out roles in his 
daily life, namely as a mother, researcher, expert and as a religious Muslim. Moreover, the results of this study also show that Dalia Mogahed shapes and changes her identity according to its context. This proves that a person's identity is not fixed, but changes according to the situation and condition of each individual (Omoniyi, T. \& White, G, 2006)

Since this research deals with the identity representation in term of speech within the sociolinguistics approach, is highly recommended for further researchers who are in passion for doing the same investigation in identity projection to follow up the findings of this research by investigating the personal identity through the someone's speech. Because during investigating this study, the researcher does not find a personal identity representation to be shared through the speech performance. Additionally, in the end, this research hopefully could inspire the other researcher in delivering criticism to accomplish the gap of this research.

\section{REFERENCES}

Azizah, Dewi Musfirotul (2014). The Identity of J.K. Rowling as Reflected On The Interview In Operah Winfrey Show. Malang. UIN Press.

Benwell, B. \& Stokoe, E (2006). Discourse and Identity. Edinburgh. University Press.

Blommeart, J. (2005). Discourse; Key Topic in Sociolinguistics. New York. Cambridge University Press.

Block, D. (2007). Second language identities. London: Continuum.

Challouki, Hanan (2015). Inspiring Muslim Women: Dalia Mogahed, The First Hijabi In The White House. Muslim Ispires. Retrieved from: http://mvslim.com/inspiring-muslimwomen-dalia-mogahed-the-first- hijabi-in-the-white-house/

Dornyei, Z. (2007). Research Methods in Applied Linguistics Quantitative, Qualitative and Mixed Methodologies. United Kingdom. Oxford University Press.

Hall, Stuart (1997). Representation: Cultural Representation and Signifying Practice. London. Sage Publications.

Hyland, K. \& Paltridge (2011). Continuum Companion to Discourse Analysis. London. Continuum.

Mercer, Kobena (1997). In Kathryn Woodward, Identity and Difference. London. Sage Publications.

Miles, M.B \& Huberman, A.M (1994). Qualitative Data Analysis. London. Sage Publication.

Newman, David (2012). Identities and Inequalities: Exploring The Intersection Of Race, Class, Gender, And Sexuality. USA. Mcgraw-Hill.

Oldham, John M., and Lois B. Morris. The New Personality Self-Portrait: Why You Think, Work, Love, and Act the Way You Do. Rev. ed. New York: Bantam, 1995.

Omoniyi, T. \& White, G. (2006). The Sociolinguistics of Identity. London: Continum. 
Paltridge, B (2006). Discourse Analysis: An Introduction. London and New York.

Continuum.

Pearson 2012. Nonverbal Communicatin. Fundamental of Communication Studies.

Peter J. Burke and Jan E. Stets. (2009). Identity Theory. USA. Oxford University Press.

Susilowati, Meinarni (2014). A Conceptual Review On Linguistic Approaches of Identity Investigation. LINGUA. Vol. 9, No. 2, -ISSN 1693-4725.

Susilowati, Meinarni (2010). Investigating Teacher Identity Representation In Classroom Interaction. Seminar Lokakarya Nasional: Penelitian Tindakan Kelas Dalam Perspektif Etnografi.

TED Talks. What do you think when you look at me?. Retrieved from: https://www.youtube.com/watch?v=wzkFoetp- M https://www.ted.com/talks/dalia mogahed what do you think wh en you look at me/transcript?sf59966917=1

Woodward, Kathryn (1997). Identity and difference. London. Sage Publication. 
90 I Zaenul Kurniawan Syahid 